\title{
Energy security aspects related to the National Power Grid
}

\author{
Nicolae Daniel Fita ${ }^{1 *}$, Dragos Pasculescu ${ }^{1}$, Florin Gabriel Popescu ${ }^{1}$, Alina Daniela \\ Handra $^{1}$, and Emilia Grigorie $^{1}$ \\ ${ }^{1}$ University of Petrosani, Universitatii Street, No.20, Petrosani, Romania
}

\begin{abstract}
National Power Grid is an important element within the National Power System, having in its composition critical infrastructures of national importance without which the national economy could not operate, and its non-operation, totally or partially (black/brown-out), generates energy insecurity, negative factor with devastating and catastrophic effects on industrial, economic and national security. Due to the fact that National Power Grid is of national strategic importance, it has to be assessed and monitored permanently in terms of security risks, in order to identify vulnerabilities, and this need for assessment also comes from the European perspective because Romania is interconnected to ENTSO-E (European Network of Transmission System Operators) which interconnects various power overhead lines from North to South, from West to East, or even with Africa and Asia. In order to secure the National Power Grid, the authors have set out in this paper to identify possible internal or external vulnerabilities and what impact they have on the National Power Grid and National Power System. By knowing the vulnerabilities, one can automatically identify the dangers and threats to which it is subjected and engaged, being able to develop national/European measures or strategies for the protection and security of the critical infrastructures related to. For this reason, it is considered that the identification of vulnerabilities must become a pressing issue of national, and European energy security and be a useful tool for authorities to develop a energy strategy (short - long term) for the proper functioning of the National Power Grid and the national economy, because all sectors of the economy depend on electricity. The identified vulnerabilities are eliminated by National Energy Strategy $2021-2036$ (short, medium,and long term) proposed by the authors, with the aim of increasing energy and national security.
\end{abstract}

\section{General information regarding energy security}

As we know, while we are facing an increase for the cases of energy collapses around the world, although this is manifested by the lack of electricity (phenomenon described by blackout) in industrial and household consumers, makes this paper of great importance and relevance, knowing that there are critical power infrastructure that can be vulnerable to some several internal or even external factors [1-3]. The lack of electricity supply to industrial and

* Corresponding author: daniel.fita@yahoo.com 
household consumers leads to national crises that cause a state of societal imbalance causing extreme damage to the safety of citizens, industry, the national economy and thus national security, because all sectors of a national economy depend on electricity. In this context, the National Power System - NPS, through the National Power Grid - NPG, becomes a strategic objective of national importance by generating national and European critical infrastructures, without which the national economy cannot function properly [4-6]. Romania's energy security depends on the energy independence in the context of the sustainable development of the European Union, therefore the energetic stability factors must be created by: providing the necessary primary resources (natural gas, oil, coal, uranium, etc.) for the engendering of electricity and therefore limiting the dependence on imports; enlarging provided natural resources considering the import for producing electrical energy and by its ways for the distribution; increasing the adequacy and safety of national transmission networks for electricity and gas outages; protection of the critical infrastructure regarding the physical integrity of energy purposes; securing workplaces and personnel by avoiding and/or stopping technical accidents/ incidents that could lead to disruption of the NPS [7-9].

But Romania's energy security is endangered by various elements of instability that may threaten the safety and security of NPG: vulnerabilities (natural and anthropogenic hazards); threats (terrorist acts, political instability, armed conflict and piracy); dangers (lack of supply of raw materials necessary for the production of electricity, use of electricity as a weapon or pressure tool, high costs of electricity, etc.)[10].

In order to stabilize and increase energy security, the NPG must be constantly subject to security assessments to identify vulnerabilities, risks, dangers or threats, in order to prevent, combat or eliminate these sources of instability that may lead to NPS insecurity and general insecurity, and the recommendation is that these identification and evaluation processes be carried out more preventively than corrective [11].

\section{Description of the NPG}

The NPG infrastructure is as follows, according to Figure 1:

- 81 power substations, from which: 1 power substation of $750 \mathrm{kV} ; 38$ power substations of $400 \mathrm{kV}$; 42 power substations of $220 \mathrm{kV}$;

- $8931.6 \mathrm{~km}$ overhead power lines - OHL, from which: 154,6 km. - 750 kV; 4703,7 km. $-400 \mathrm{kV} ; 4035,2 \mathrm{~km}$. $-220 \mathrm{kV}$;

- 218 distribution units totalling 37794 MVA [12-14].

Table 1. Power substations within NPG

\begin{tabular}{|c|c|c|}
\hline \multicolumn{3}{|c|}{ POWER SUBSTATIONS } \\
\hline $750 \mathrm{kV}$ & $400 \mathrm{kV}$ & $220 \mathrm{kV}$ \\
\hline 750/400 kV Isaccea* & $\begin{array}{l}\text { 400/220/110 kV South } \\
\text { Bucharest; } \\
\text { 400/110 kV Domnești; } \\
\text { 400/220/110 kV Iernut; } \\
\text { 400/220/110 kV South Sibiu; } \\
\text { 400/110 kV Dârste; } \\
\text { 400/110 kV Braşov; } \\
\text { 400/220/110 kV Gutinaș; } \\
\text { 400/220/110 kV Suceava; } \\
\text { 400/110 kV South Bacău; } \\
\text { 400/110 kV North Roman; } \\
\text { 400 kV Stupina; } \\
\text { 400 kV Rahman; } \\
\text { 400/220/110 kV Lacu Sărat; }\end{array}$ & $\begin{array}{l}\text { 220/110 kV Fundeni; } \\
\text { 220/110 kV Gheorgheni; } \\
\text { 220/110 kV Fântânele; } \\
\text { 220/110 kV Ungheni; } \\
\text { 220/110 kV Alba Iulia; } \\
\text { 220/110 kV Munteni; } \\
\text { 220/110 kV Iași (FAI); } \\
\text { 220/110 kV Dumbrava; } \\
\text { 220/110 kV Stejaru; } \\
\text { 220/110 kV Filești; } \\
\text { 220/110 kV Bărboși; } \\
\text { 220/110 kV West Focșani; } \\
\text { 220/110 kV Stâlpu; } \\
\text { 220/110 kV Teleajen; }\end{array}$ \\
\hline
\end{tabular}




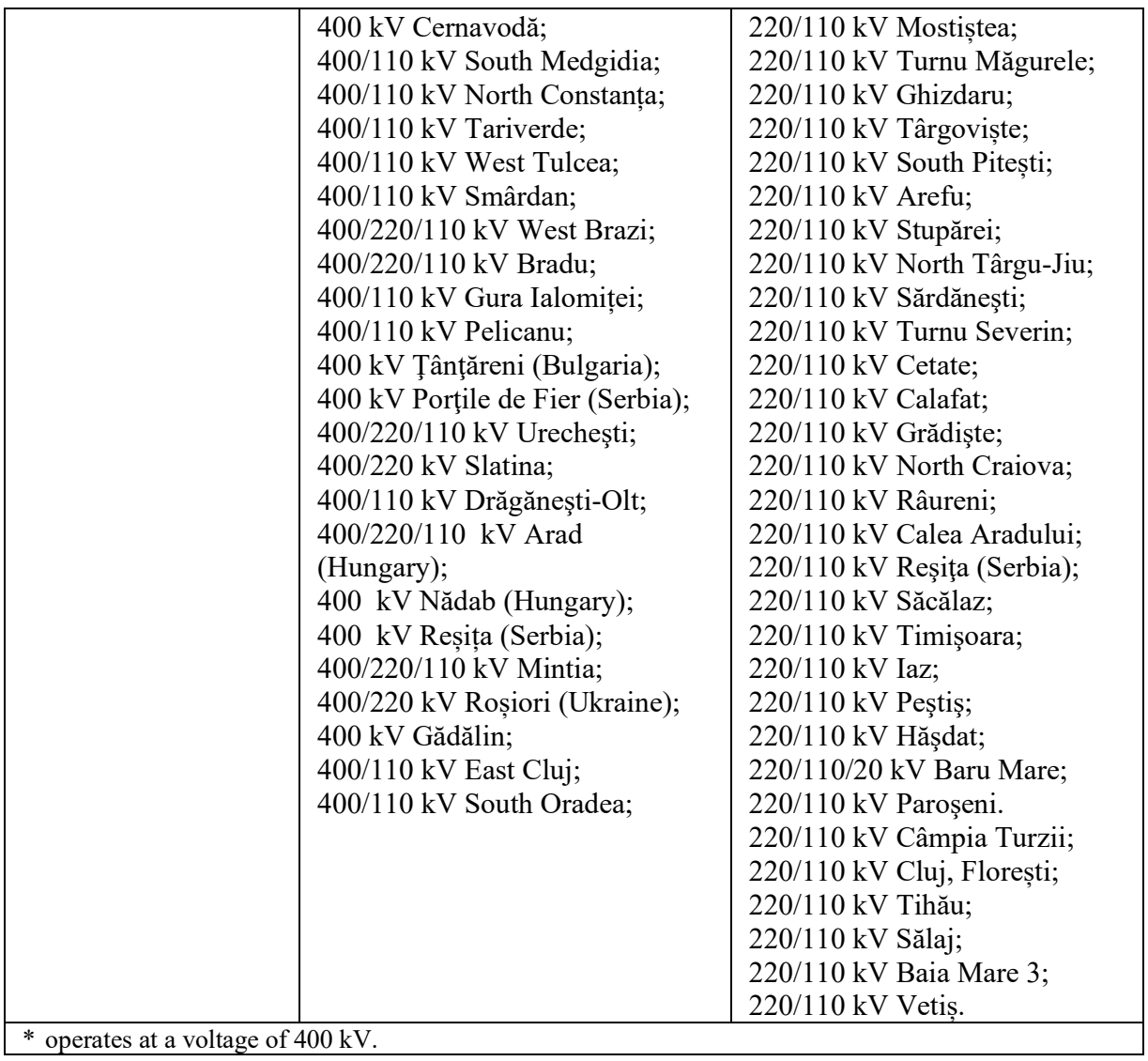

Table 2. Power overhead lines within NPG

\begin{tabular}{|c|c|}
\hline \multicolumn{2}{|c|}{ POWER OVERHEAD LINES } \\
\hline \multicolumn{2}{|c|}{ OHL $750 \mathrm{kV}$} \\
\hline $\begin{array}{l}750 \mathrm{kV} \text { Isaccea - South Ukraine (Ukraine) } \\
750 \mathrm{kV} \text { Isaccea - Stupina (Romania) - ope } \\
750 \mathrm{kV} \text { Stupina - Varna (Bulgaria) - opera }\end{array}$ & $\begin{array}{l}\text { disused OHLpla; } \\
\text { es at a voltage of } 400 \mathrm{kV} \text {; } \\
\text { at a voltage of } 400 \mathrm{kV} \text {. }\end{array}$ \\
\hline OHL $400 \mathrm{kV}$ & OHL $220 \mathrm{kV}$ \\
\hline $\begin{array}{l}400 \text { kV South Bucharest - Domnești; } \\
400 \text { kV South Bucharest - Gura Ialomiței; } \\
400 \text { kV South Bucharest - Pelicanu; } \\
400 \text { kV South Bucharest - Slatina; } \\
400 \text { kV Domnești - West Brazi; } \\
400 \text { kV Iernut - Gădălin; } \\
400 \text { kV Iernut - South Sibiu; } \\
400 \text { kV South Sibiu - Mintia; } \\
400 \text { kV South Sibiu - Ţânțăreni; } \\
400 \text { kV South Sibiu - Braşov; } \\
400 \text { kV Braşov - Bradu; } \\
400 \text { kV Braşov - Dârste; } \\
400 \text { kV Braşov - Gutinaş; } \\
400 \text { kV Dârste - West Brazi; } \\
400 \text { kV Gutinaş - Braşov; } \\
400 \text { kV Gutinaş - South Bacău; } \\
400 \text { kV Bacău South - North Roman; } \\
400 \text { kV Roman North - Suceava; }\end{array}$ & $\begin{array}{l}220 \text { kV South Bucharest - Fundeni; } \\
220 \text { kV South Bucharest - Ghizdaru; } \\
220 \text { kV South Bucharest - Mostiştea; } \\
220 \text { kV Fundeni - West Brazi; } \\
220 \text { kV Gheorgheni - CHE Stejaru; } \\
220 \text { kV Gheorgheni - Fântânele; } \\
220 \text { kV Fântânele - Ungheni; } \\
220 \text { kV Ungheni - Iernut; } \\
220 \text { kV Iernut - Baia Mare 3; } \\
220 \text { kV Iernut - Câmpia Turzii; } \\
220 \text { kV South Sibiu - CHE Lotru; } \\
220 \text { kV Alba Iulia - Mintia; } \\
220 \text { kV Alba Iulia - CHE Șugag; } \\
220 \text { kV Alba Iulia - CHE Gâlceag; } \\
220 \text { kV Alba Iulia - Cluj Floreşti. } \\
220 \text { kV Gutinaș - Dumbrava; } \\
220 \text { kV Gutinaş - CTE Borzeşti; } \\
220 \text { kV Gutinas - Munteni; }\end{array}$ \\
\hline
\end{tabular}




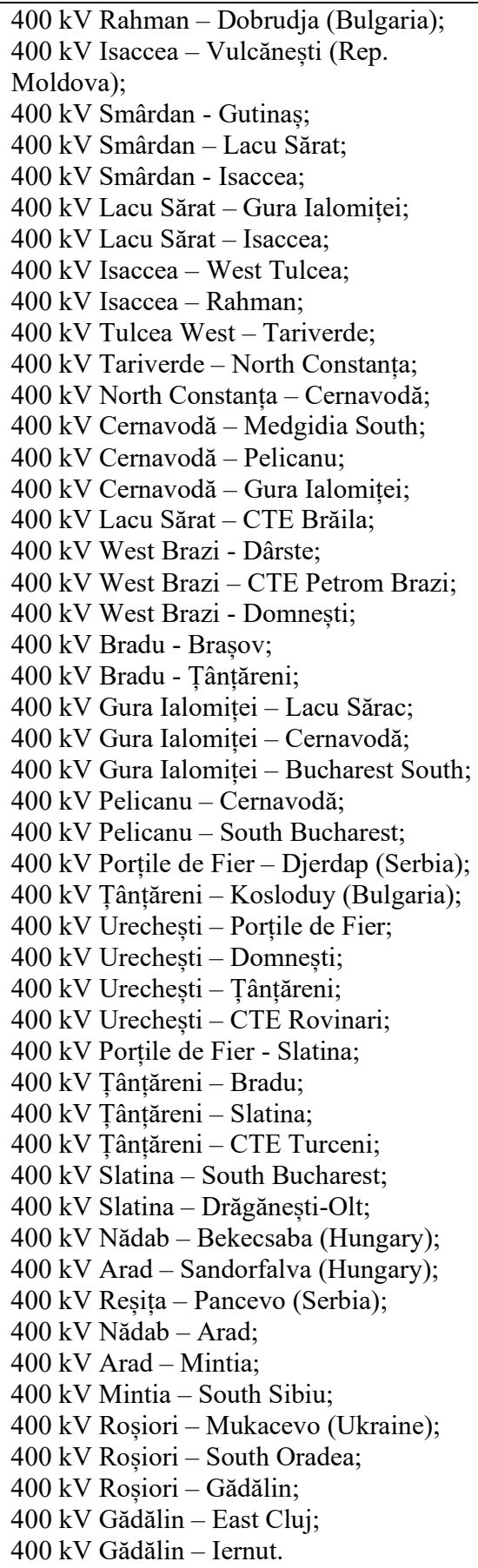

220 kV Gutinaş - Iaşi (FAI);

220 kV Iaşi (FAI) - Munteni;

220 kV Iași (FAI) - Suceava;

220 kV Dumbrava - CHE Stejaru;

220 kV CHE Stejaru - Gheorgheni.

220 kV West Focşani - Gutinaş;

220 kV West Focșani - Bărboși;

220 kV Bărboși - Filești;

220 kV Lacu Sărat - CTE Brăila;

220 kV Teleajen - West Brazi;

220 kV Teleajen - Stâlpu;

220 kV Mostiştea - South Bucharest;

220 kV Turnu Măgurele - Ghizdaru;

220 kV Turnu Măgurele - North Craiova;

220 kV Ghizdaru - South Bucharest;

220 kV Târgoviște - West Brazi;

220 kV Târgoviște - Bradu;

220 kV South Pitești - Bradu;

$220 \mathrm{kV}$ Arefu - CHE Vidraru;

220 kV Arefu - Râureni;

220 kV Bradu - Stupărei.

220 kV Urechești - North Târgu Jiu;

220 kV Urechești - Sărdănești;

220 kV Sărdănești - North Craiova;

220 kV North Craiova - Slatina;

220 kV North Craiova - Turnu Măgurele;

220 kV CTE Ișalnița - Grădiște;

220 kV Grădiște - Slatina;

220 kV Porțile de Fier - Reșița;

220 kV Porțile de Fier - Turnu Severin;

220 kV Porțile de Fier - Cetate;

$220 \mathrm{kV}$ Cetate - Calafat;

220 kV Râureni - Arefu;

220 kV Râureni - Stupărei;

220 kV Stupărei - Bradu;

220 kV North Craiova - CTE Ișalnița;

220 kV CHE Lotru - South Sibiu.

220 kV Arad - Calea Aradului;

220 kV Arad - Timişoara;

220 kV Calea Aradului - Săcălaz;

220 kV Săcălaz - Timișoara;

220 kV Timişoara - Mintia;

220 kV Timișoara - Reșița;

220 kV Reșița - Iaz;

220 kV Reșița - Porțile de Fier;

220 kV Mintia - Pestiş;

220 kV Mintia - Hăşdat;

220 kV Mintia - Alba Iulia;

220 kV Hășdat - Pestiș;

220 kV Hăş̧at - CHE Retezat;

220 kV Hășdat - Baru Mare;

220 kV Baru Mare - Paroșeni;

220 kV Paroșeni - North Târgu Jiu;

220 kV Roşiori - Vetiș;

220 kV Roşiori - Baia Mare 3;

220 kV Baia Mare 3 - Tihău;

220 kV Baia Mare 3 - Iernut; 


\begin{tabular}{|l|l|}
\hline & 220 kV Tihău - Sălaj; \\
& 220 kV Tihău - Cluj, Florești; \\
& 220 kV Cluj, Florești - CHE Mărișelu; \\
& 220 kV Cluj, Florești - Câmpia Turzii; \\
& 220 kV Cluj, Florești - Alba Iulia; \\
& 220 kV Câmpia Turzii - Iernut. \\
\hline
\end{tabular}

Table 3. Power plant within NPG

\begin{tabular}{|l|}
\hline POWER PLANT \\
\hline Thermal power plant South Bucharest - 270 MW (eviction of $400 \mathrm{kV}) ;$ \\
Thermal power plant Iernut - 563 MW (eviction of $400 \mathrm{kV}) ;$ \\
Hydro power plant Șugag - 149 MW (eviction of $220 \mathrm{kV}) ;$ \\
Hydro power plant Gâlceag - 149 MW (eviction of $220 \mathrm{kV}) ;$ \\
Hydro power plant Stejaru - 143 MW (eviction of $220 \mathrm{kV}) ;$ \\
Thermal power plant Borzești - 210 MW (eviction of $220 \mathrm{kV}) ;$ \\
Nuclear power plant Cernavodă - 1300 MW (eviction of $400 \mathrm{kV}) ;$ \\
Eolian power plant Stupina - 278 MW (eviction of $110 \mathrm{kV}) ;$ \\
Eolian power plant Rahman - 242 MW (eviction of $110 \mathrm{kV}) ;$ \\
Thermal power plant Brăila - 210 MW (eviction of $400 \mathrm{kV}) ;$ \\
Thermal power plant Petrom Brazi - 850 MW (eviction of $400 \mathrm{kV}) ;$ \\
Eolian power plant Făcăeni - 132 MW (eviction of $400 \mathrm{kV}) ;$ \\
Hydro power plant Vidraru - 219 MW (eviction of $220 \mathrm{kV}) ;$ \\
Hydro power plant Porțíle de Fier - 1080 MW (eviction of $400 \mathrm{kV}) ;$ \\
Thermal power plant Turceni - 1196 MW (eviction of $400 \mathrm{kV}) ;$ \\
Thermal power plant Rovinari - 888 MW (eviction of $400 \mathrm{kV}) ;$ \\
Thermal power plant Ișalnița - 582 MW (eviction of $220 \mathrm{kV}) ;$ \\
Hydro power plant Lotru - 509 MW (eviction of $220 \mathrm{kV}) ;$ \\
Thermal power plant Mintia - 930 MW (eviction of $400 \mathrm{kV}) ;$ \\
Thermal power plant Paroșeni - 133 MW (eviction of $220 \mathrm{kV}) ;$ \\
Hydro power plant Retezat - 210 MW (eviction of $220 \mathrm{kV}) ;$ \\
Hydro power plant Mărișelu - 215 MW (eviction of $220 \mathrm{kV})$. \\
\hline
\end{tabular}

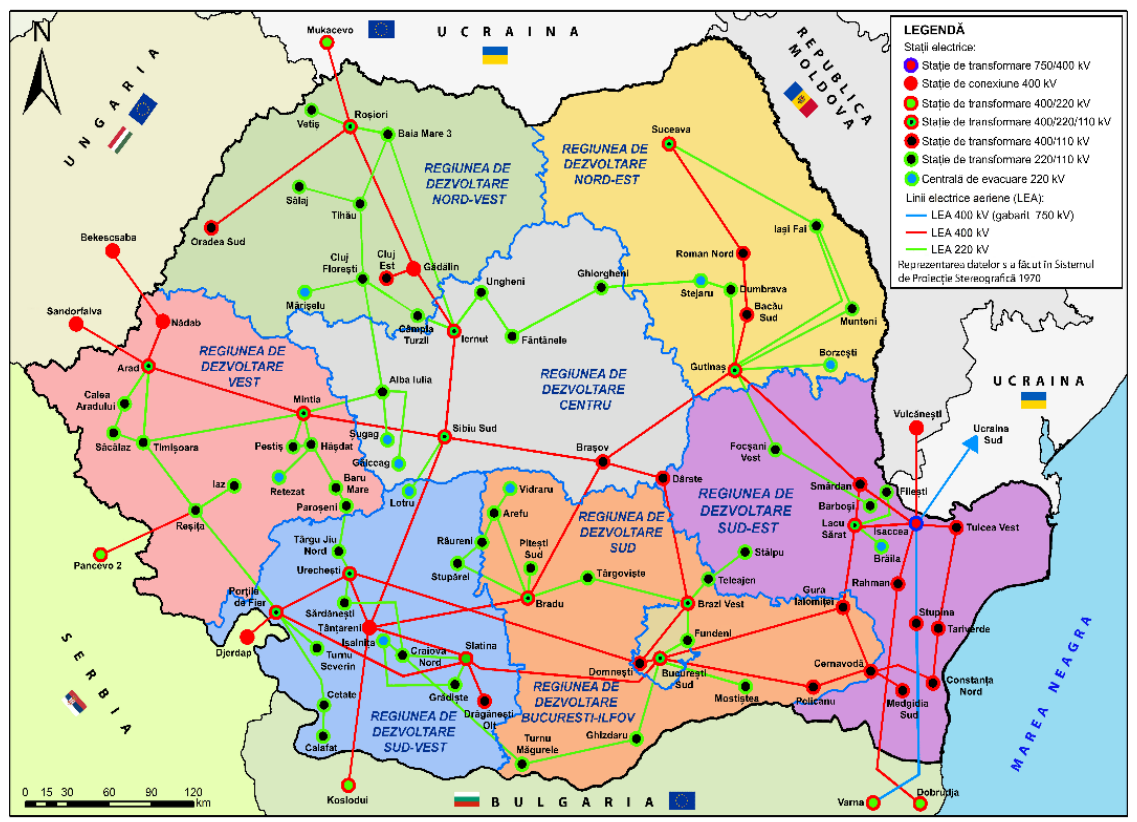

Fig. 1. NPG map (map's legend is presented in Romanian) 
Table 4. Cross-border power infrastructures within NPG

\begin{tabular}{|c|c|}
\hline POWERS SUBSTATIONS & $\begin{array}{l}\text { POWER OVERHEAD LINES } \\
\end{array}$ \\
\hline $\begin{array}{l}750 \mathrm{kV} \text { Isaccea* } \rightarrow \text { Ukraine and } \\
\text { Moldova; } \\
400 \mathrm{kV} \text { Stupina** } \rightarrow \text { Bulgaria; } \\
400 \mathrm{kV} \text { Rahman } \rightarrow \text { Bulgaria; } \\
400 \mathrm{kV} \text { Țânțăreni } \rightarrow \text { Bulgaria; } \\
400 \mathrm{kV} \text { Porțile de Fier } \rightarrow \text { Serbia; } \\
400 \mathrm{kV} \text { Reșița } \rightarrow \text { Serbia; } \\
400 / 220 / 110 \mathrm{kV} \text { Arad } \rightarrow \text { Hungary; } \\
400 \mathrm{kV} \mathrm{Nădab} \rightarrow \text { Hungary; } \\
400 / 220 \text { kV Roșiori } \rightarrow \text { North Ukraine. }\end{array}$ & $\begin{array}{l}750 \mathrm{kV} \text { Isaccea* } \rightarrow \text { South Ukraine (South Ukraine); } \\
750 \mathrm{kV} \text { Stupina** } \rightarrow \text { Varna (Bulgaria); } \\
400 \mathrm{kV} \text { Isaccea } \rightarrow \text { Vulcănești (Rep. Moldova); } \\
400 \mathrm{kV} \text { Rahman } \rightarrow \text { Dobrudja (Bulgaria); } \\
400 \mathrm{kV} \text { Țânțăreni } \rightarrow \text { Kosloduy (Bulgaria); } \\
400 \mathrm{kV} \text { Porțile de Fier } \rightarrow \text { Djerdap (Serbia); } \\
400 \mathrm{kV} \text { Reșița } \rightarrow \text { Pancevo (Serbia); } \\
400 \mathrm{kV} \text { Arad } \rightarrow \text { Sandorfalva (Hungary); } \\
400 \mathrm{kV} \text { Nădab } \rightarrow \text { Bekescsaba (Hungary); } \\
400 \mathrm{kV} \text { Roșiori } \rightarrow \text { Mukacevo (North Ukraine). }\end{array}$ \\
\hline $\begin{array}{l}* \text { operates at a voltage of } 400 \mathrm{kV} \\
* * \text { gabarit of } 750 \mathrm{kV}\end{array}$ & $\begin{array}{l}\text { * disused lines; } \\
* * \text { operates at a voltage of } 400 \mathrm{kV}\end{array}$ \\
\hline
\end{tabular}

\section{Measures and proposals concerning the operational security of NPG and increasing energy security}

\subsection{Identifying vulnerabilities}

a) Internal vulnerabilities with internal impact within NPG, according to the table 5 .

Table 5. Internal vulnerabilities with internal impact within NPG

\begin{tabular}{|c|c|}
\hline \multicolumn{2}{|r|}{ INTERNAL VULNERABILITIES WITH INTERNAL IMPACT WITHIN NPG } \\
\hline 1. & $\begin{array}{l}\text { Development region for BUCHAREST - ILFOV: } \\
\text { Failure to close the } 400 \mathbf{k V} \text { ring in the area of Bucharest and Ilfov County } \\
\text { (South Bucharest - Domnesti - West Brazi - Fundeni - South Bucharest). }\end{array}$ \\
\hline 2. & $\begin{array}{l}\text { Development region for CENTER: } \\
\text { Failure to close the } 400 \mathbf{~ k V} \text { ring in the northern and western areas of the North-East } \\
\text { region (Iernut - South Sibiu - Brașov - Gutinaș - Dumbrava - Stejaru - Gheorgheni - } \\
\text { Fântânele - Ungheni - Iernut). }\end{array}$ \\
\hline 3. & $\begin{array}{l}\text { Development region for NORTH-EAST: } \\
\text { Failure to close the } \mathbf{4 0 0} \mathbf{k V} \text { ring in the north-est areas of the North-East region (Gutinaș } \\
\text { - Munteni - Iași FAI - Suceava). }\end{array}$ \\
\hline 4. & $\begin{array}{l}\text { Development region for NORTH - EAST: } \\
\mathbf{4 0 0} \mathbf{~ k V} \text { radial distribution Gutinas - Suceava (Gutinaș - South Bacău - North Roman - } \\
\text { Suceava). }\end{array}$ \\
\hline 5. & $\begin{array}{l}\text { Development region for } S O U T H \text { - EAST: } \\
\text { Failure to close the } \mathbf{4 0 0} \mathbf{k V} \text { ring in the northern part of the South-East region (Lacu Sărat } \\
\text { - Filești - Bărboși - West Focșani- Gutinaș). }\end{array}$ \\
\hline 6. & $\begin{array}{l}\text { Development region for SOUTH - EAST: } \\
\text { Missing the european interconnection between } \mathbf{4 0 0} \mathbf{~ k V} \text { Sandorfalva - Arad and } \mathbf{4 0 0} \mathbf{~ k V} \\
\text { Cernavodă power plant (Sandorfalva - Arad - Mintia - South Sibiu - Brașov - Dârste) } \\
\text { - (Dârste - Stâlpu - Gura Ialomiței - Cernavodă). }\end{array}$ \\
\hline 7. & $\begin{array}{l}\text { Development region for SOUTH: } \\
\text { Failure to close the } 400 \mathbf{k V} \text { ring in the central area of the South region (West Brazi - } \\
\text { Târgoviște - Bradu - Brașov - Dârste - West Brazi). }\end{array}$ \\
\hline 8. & $\begin{array}{l}\text { Development region for SOUTH: } \\
\text { Failure closing for the } 400 \mathrm{kV} \text { ring (or doubling the ring) in the southern part of the } \\
\text { South region and the southern part of the South-West region (South Bucharest - } \\
\text { Ghizdaru - Turnu Măgurele) and (Turnu Măgurele - North Craiova - Sărdănești - } \\
\text { Urechești). }\end{array}$ \\
\hline 9. & Development region for $S O U T H-W E S T:$ \\
\hline
\end{tabular}




\begin{tabular}{|l|l|}
\hline & $\begin{array}{l}\text { Failure closing for the } \mathbf{4 0 0} \mathbf{k V} \text { ring (or doubling the ring) in the southern part of the } \\
\text { South-West region and the southern part of the South region (Turnu Măgurele - North } \\
\text { Craiova- Sărdănești - Urechești) and (South Bucharest - Ghizdaru - Turnu Măgurele). }\end{array}$ \\
\hline 10. & $\begin{array}{l}\text { Development region for WEST: } \\
\text { Failure to close the } 400 \mathbf{k V} \text { ring in the western part of the Western region (Arad - Calea } \\
\text { Aradului - Săcălaz - Timișoara). }\end{array}$ \\
\hline 11. & $\begin{array}{l}\text { Development region for WEST: } \\
\text { Failure to close the } \mathbf{4 0 0} \mathbf{k V} \text { ring in the central area of the West region (Arad - Mintia - } \\
\text { Timișoara). }\end{array}$ \\
\hline 12. & $\begin{array}{l}\text { Development region for WEST: } \\
\text { Failure to close the } \mathbf{4 0 0} \mathbf{k V} \text { ring in the eastern part of the Western region (Mintia - } \\
\text { Hășdat - Baru Mare - Paroșeni - Târgu Jiu Nord - Urechești) and (Urechești - Porțile } \\
\text { de Fier - Reșița - Timișoara - Arad - Mintia). }\end{array}$ \\
\hline 13. & $\begin{array}{l}\text { Development region for WEST: } \\
\text { Failure to close the } \mathbf{4 0 0} \mathbf{k V} \text { ring in the eastern part of the Western region (Mintia - } \\
\text { Hășdat - Pestiș). }\end{array}$ \\
\hline $\begin{array}{l}\text { LEGEND: } \\
\text { Red color: Power Critical Infrastructures (power substation and OHL) for } 400 \mathrm{kV} \text {; } \\
\text { Green color: Power Critical Infrastructures (power substation and OHL) } 220 \mathrm{kV} .\end{array}$ \\
\hline
\end{tabular}

b) External vulnerabilities with external impact within NPG, according to the table 6 .

Table 6. External vulnerabilities with external impact within NPG

\begin{tabular}{|c|l|}
\hline \multicolumn{2}{|c|}{ EXTERNAL VULNERABILITIES WITH EXTERNAL IMPACT WITHIN NPG } \\
\hline 1. & $\begin{array}{l}\text { Development region for NORTH - EAST: } \\
\text { Missing the international interconnection voltage of } \mathbf{4 0 0} \mathbf{~ k V} \text { in the North of North - West } \\
\text { and North - East Romania (Suceava - Bălți). }\end{array}$ \\
\hline 2. & $\begin{array}{l}\text { Development region for NORTH - EAST: } \\
\text { Failure to close the } \mathbf{4 0 0} \mathbf{k V} \text { ring in the northern part of Romania (Suceava - Roșiori) or } \\
\text { (Suceava - Gădălin). }\end{array}$ \\
\hline 3. & $\begin{array}{l}\text { Development region for WEST: } \\
\text { Failure to close the } \mathbf{4 0 0} \mathbf{k V} \text { ring in the western part of the Western region and Romania } \\
\text { (Arad - Timișoara - Reșita - Porțile de Fier). }\end{array}$ \\
\hline 4. & $\begin{array}{l}\text { Development region for NORTH - WEST: } \\
\text { Failure to close the } \mathbf{4 0 0} \mathbf{k V} \text { ring in the western part of the western region and Romania } \\
\text { (South Oradea - Nădab). }\end{array}$ \\
\hline $\begin{array}{l}\text { LEGEND: } \\
\text { Red color: Power Critical Infrastructures (power substation and } O H L \text { ) for } 400 \mathrm{kV} ; \\
\text { Green color: Power Critical Infrastructures (power substation and } O H L \text { ) } 220 \mathrm{kV} .\end{array}$ \\
\hline
\end{tabular}

c) External vulnerabilities within neighbouring power systems with internal impact on NPG, according to the table 7 [15].

Table 7. External vulnerabilities within neighbouring power systems with internal impact on NPG

\begin{tabular}{|l|l|}
\hline \multicolumn{2}{|c|}{ EXTERNAL VULNERABILITIES WITHIN NEIGHBOURING POWER SYSTEM WITH } \\
\hline \multicolumn{1}{|c|}{ INTERNAL IMPACT ON NPG } \\
1. & $\begin{array}{l}\text { REPUBLIC OF MOLDOVA: } \\
\text { Total dependence to the IPS (Integrated Power System) Power System of the former } \\
\text { Soviet Union countries following components: Belarus, Ukraine, Moldova, Kazakhstan, } \\
\text { Georgia, Mongolia, Kyrgyzstan, Azerbaijan, Tajikistan (power weapon or pressure tool). }\end{array}$ \\
\hline 2. & $\begin{array}{l}R E P U B L I C \text { OF } M O L D O V A: \\
\text { The voltage of } 330 \mathrm{kV} \text { (atypical EU) which is specific only to IPS (Integrated Power } \\
\text { System), which creates dependence on this power system and makes it almost impossible } \\
\text { to interconnect to another power system (eg Romanian EEA), without major investments } \\
\text { in power infrastructure power stations, overhead power lines and power plants) (power } \\
\text { weapon or pressure tool). }\end{array}$ \\
\hline
\end{tabular}




\begin{tabular}{|l|l|}
\hline 3. & REPUBLIC OF MOLDOVA: \\
The single radial distribution bus of energy (HV-OHL) voltage of $330 \mathrm{kV}$ (atypical EU) \\
[CERS Moldova - Chișinău - Strășeni - Bălți - Dnistrovska (Ukraine)].
\end{tabular}

\subsection{Drawing up the National Energy Strategy $2021-2036$}

The National Energy Strategy (short, medium and long term) following proposed solutions by the authors to eliminate (combat) the internal or external vulnerabilities of the NPG, according to the table 8 .

Table 8. National Energy Strategy 2021 - 2036 (short, medium and long term)

\begin{tabular}{|c|c|c|c|}
\hline \multicolumn{2}{|r|}{$\begin{array}{l}\text { THE SOLUTIONS REGARDING THE ELIMINATION OF } \\
\text { INTERNAL OR EXTERNAL VULNERABILITY OF NPG }\end{array}$} & $\begin{array}{c}\text { Importance } \\
\text { I } \\
\text { (Important) } \\
\text { VI } \\
\text { (Very } \\
\text { Important) } \\
\text { U } \\
\text { (Urgently) }\end{array}$ & $\begin{array}{c}\text { Period } / \\
\text { Term } \\
\text { S }- \text { Short } \\
(1-5 \text { years }) \\
\text { M }- \text { Medium } \\
(5-10 \text { years }) \\
\text { L }- \text { Long } \\
(10-15 \\
\text { years })\end{array}$ \\
\hline 1 & $\begin{array}{l}\text { 1.1. Passing OHL } 220 \mathrm{kV} \text { București Sud - Fundeni to } 400 \\
\mathrm{kV} \text { voltage }\end{array}$ & VI & $\mathbf{M}$ \\
\hline
\end{tabular}




\begin{tabular}{|c|c|c|c|}
\hline & $\begin{array}{l}\text { 1.2. Passing OHL } 220 \mathrm{kV} \text { Fundeni - West Brazi to } 400 \mathrm{kV} \\
\text { voltage }\end{array}$ & & \\
\hline & 1.3. Passing PS $220 \mathrm{kV}$ Fundeni to $400 \mathrm{kV}$ voltage & & \\
\hline 2 & $\begin{array}{l}\text { 2.1. Passing OHL } 220 \mathrm{kV} \text { Iernut - Ungheni - Fântânele - } \\
\text { Gheorgheni - Stejaru - Dumbrava - Gutinaş to } 400 \mathrm{kV} \\
\text { voltage }\end{array}$ & VI & M \\
\hline & $\begin{array}{l}\text { 2.2. Passing PS } 220 \mathrm{kV} \text { Ungheni, Fântânele, Gheorgheni, } \\
\text { Stejaru, Dumbrava to } 400 \mathrm{kV} \text { voltage }\end{array}$ & & \\
\hline & $\begin{array}{l}\text { 3.1. Passing OHL } 220 \mathrm{kV} \text { Gutinaș - Munteni - Iaşi (FAI) - } \\
\text { Suceava to } 400 \mathrm{kV} \text { voltage }\end{array}$ & & \\
\hline 3 & $\begin{array}{l}\text { 3.2. Passing OHL } 220 \mathrm{kV} \text { Gutinaș - Iași (FAI) to } 400 \mathrm{kV} \\
\text { voltage }\end{array}$ & VI & $\mathbf{M}$ \\
\hline & $\begin{array}{l}\text { 3.3. Passing PS } 220 \mathrm{kV} \text { Munteni, Iaşi (FAI) to } 400 \mathrm{kV} \\
\text { voltage }\end{array}$ & & \\
\hline 4 & $\begin{array}{l}\text { 4.1. The construction of a OHL } 400 \mathrm{kV} \text { to double the power } \\
\text { supply to the OHL Suceava - Gutinass, also serving to close } \\
\text { the } 400 \mathrm{kV} \text { ring in the northern part of the country. } \\
\text { There are } 2 \text { possibilities: } \\
\text { - } \quad \text { the construction OHL } 400 \mathrm{kV} \text { Gădălin - Suceava at } 400 \\
\quad k V \text { voltage; } \\
\text { - the construction OHL } 400 \mathrm{kV} \text { Roșiori - Suceava at } 400 \\
\quad k V \text { voltage. }\end{array}$ & $\mathbf{U}$ & $\mathbf{S}$ \\
\hline 5 & $\begin{array}{l}\text { 5.1. Passing OHL } 220 \mathrm{kV} \text { Lacu Sărat - Filești - Bărboși - } \\
\text { Focșani Vest - Gutinaș to } 400 \mathrm{kV} \text { voltage }\end{array}$ & VI & $\mathbf{M}$ \\
\hline J & $\begin{array}{l}\text { 5.2. Passing PS } 220 \mathrm{kV} \text { Focşani Vest, Bărboși, Filești to } 400 \\
\mathrm{kV} \text { voltage }\end{array}$ & $\sqrt{1}$ & 10 \\
\hline 6 & $\begin{array}{l}\text { 6.1. The construction of a OHL } 400 \mathrm{kV} \text { for the } \\
\text { interconnection of the European bus } 400 \mathrm{kV} \text { Sandorfalva - } \\
\text { Arad with the } 400 \mathrm{kV} \text { Cernavoda power substation. } \\
\text { There are } 2 \text { possibilities: } \\
\text { - the construction OHL } 400 \mathrm{kV} \text { Dârste - Stâlpu - Gura } \\
\text { Ialomitei; } \\
\text { - the construction OHL } 400 \mathrm{kV} \text { Braşov - Stâlpu - } \\
\text { Cernavoda. }\end{array}$ & VI & $\mathbf{M}$ \\
\hline & $\begin{array}{l}\text { 6.2. Passing OHL } 220 \mathrm{kV} \text { Brazi Vest - Teleajen - Stâlpu to } \\
400 \mathrm{kV} \text { voltage }\end{array}$ & & \\
\hline & $\begin{array}{l}\text { 6.3. Passing PS } 220 \mathrm{kV} \text { Teleajen and Stâlpu to } 400 \mathrm{kV} \\
\text { voltage }\end{array}$ & & \\
\hline 7 & $\begin{array}{l}\text { 7.1. Passing OHL } 220 \mathrm{kV} \text { Bradu - Târgoviște - Brazi Vest } \\
\text { to } 400 \mathrm{kV} \text { voltage }\end{array}$ & I & $\mathbf{L}$ \\
\hline & 7.2. Passing PS $220 \mathrm{kV}$ Târgoviște to $400 \mathrm{kV}$ voltage & & \\
\hline & $\begin{array}{l}\text { 8.1. Passing OHL } 220 \mathrm{kV} \text { București Sud - Ghizdaru - Turnu } \\
\text { Măgurele to } 400 \mathrm{kV} \text { voltage }\end{array}$ & & \\
\hline 8 & $\begin{array}{l}\text { 8.2. Passing PS } 220 \mathrm{kV} \text { Ghizadru and Turnu Măgurele to } 400 \\
\mathrm{kV} \text { voltage }\end{array}$ & I & $\mathbf{L}$ \\
\hline & $\begin{array}{l}\text { 8.3. Passing OHL } 220 \mathrm{kV} \text { Bucureşti Sud - Mostiştea to } 400 \\
\mathrm{kV} \text { voltage }\end{array}$ & & \\
\hline & 8.4. Passing PS $220 \mathrm{kV}$ Mostiștea to $400 \mathrm{kV}$ voltage & & \\
\hline 0 & $\begin{array}{l}\text { 9.1. Passing OHL } 220 \mathrm{kV} \text { Turnu Măgurele - Craiova Nord } \\
\text { - Sărdănești - Urechești to } 400 \mathrm{kV} \text { voltage }\end{array}$ & & \\
\hline 9 & $\begin{array}{l}\text { 9.2. Passing PS } 220 \mathrm{kV} \text { Craiova Nord and Sărdăneşti to } 400 \\
\mathrm{kV} \text { voltage }\end{array}$ & $\mathbf{I}$ & $\mathbf{L}$ \\
\hline 10 & $\begin{array}{l}\text { 10.1. Passing OHL } 220 \mathrm{kV} \text { Timișoara - Săcălaz - Calea } \\
\text { Aradului - Arad to } 400 \mathrm{kV} \text { voltage }\end{array}$ & VI & $\mathbf{M}$ \\
\hline 10 & $\begin{array}{l}\text { 10.2. Passing PS } 220 \mathrm{kV} \text { Timișoara, Săcălaz and Calea } \\
\text { Aradului to } 400 \mathrm{kV} \text { voltage }\end{array}$ & $\sqrt{1}$ & $1 \mathbf{1}$ \\
\hline
\end{tabular}




\begin{tabular}{|c|c|c|c|}
\hline \multirow{3}{*}{11} & $\begin{array}{l}\text { 11.1. Passing OHL } 220 \mathrm{kV} \text { Arad - Timișoara to } 400 \mathrm{kV} \\
\text { voltage }\end{array}$ & \multirow{3}{*}{ VI } & \multirow{3}{*}{$\mathbf{M}$} \\
\hline & $\begin{array}{l}\text { 11.2. Passing OHL } 220 \mathrm{kV} \text { Timişoara - Mintia to } 400 \mathrm{kV} \\
\text { voltage }\end{array}$ & & \\
\hline & 11.3. Passing PS $220 \mathrm{kV}$ Timișoara to $400 \mathrm{kV}$ & & \\
\hline \multirow{2}{*}{12} & $\begin{array}{l}\text { 12.1. Passing OHL } 220 \mathrm{kV} \text { Mintia - Hăşdat - Baru Mare - } \\
\text { Paroșeni - Târgu Jiu Nord - Urechești to } 400 \mathrm{kV} \text { voltage }\end{array}$ & \multirow{2}{*}{$\mathbf{I}$} & \multirow{2}{*}{$\mathbf{L}$} \\
\hline & $\begin{array}{l}\text { 12.2. Passing PS } 220 \mathrm{kV} \text { Hășdat, Baru Mare, Paroșeni and } \\
\text { Târgu Jiu Nord to } 400 \mathrm{kV} \text { voltage }\end{array}$ & & \\
\hline \multirow[t]{2}{*}{13} & $\begin{array}{l}\text { 13.1. Passing OHL } 220 \mathrm{kV} \text { Mintia - Hășdat - Pestiş to } 400 \\
\mathrm{kV} \text { voltage }\end{array}$ & \multirow[t]{2}{*}{$\mathbf{I}$} & \multirow[t]{2}{*}{$\mathbf{L}$} \\
\hline & 13.2. Passing PS $220 \mathrm{kV}$ Hășdat and Pestiș to $400 \mathrm{kV}$ voltage & & \\
\hline 14 & $\begin{array}{l}\text { 14.1. The construction OHL } 400 \mathrm{kV} \text { Suceava - Bălți in order } \\
\text { to connect Romania with the Republic of Moldova }\end{array}$ & $\mathbf{U}$ & $\mathbf{S}$ \\
\hline 15 & $\begin{array}{l}\text { 15.1. The construction of a OHL } 400 \mathrm{kV} \text { for interconnection } \\
\text { beetween PS } 400 \mathrm{kV} \text { Suceava with PS } 400 \mathrm{kV} \text { Roșiori or } 400 \\
\mathrm{kV} \\
\text { There are } 2 \text { possibilities: } \\
\text { - the construction of the OHL } 400 \mathrm{kV} \text { Gădălin - Suceava } \\
\text { at a voltage } 400 \mathrm{kV} \text {; } \\
\text { - the construction of the OHL } 400 \mathrm{kV} \text { Roșiori - Suceava } \\
\text { at a voltage of } 400 \mathrm{kV} \text {. }\end{array}$ & $\mathbf{U}$ & $\mathbf{S}$ \\
\hline \multirow[t]{2}{*}{16} & $\begin{array}{l}\text { 16.1. Passing OHL } 220 \mathrm{kV} \text { Porțile de Fier - Reșița - } \\
\text { Timișoara - Arad to } 400 \mathrm{kV} \text { voltage }\end{array}$ & \multirow[t]{2}{*}{$\mathbf{U}$} & \multirow[t]{2}{*}{$\mathbf{S}$} \\
\hline & 16.2. Passing PS $220 \mathrm{kV}$ Timișoara to $400 \mathrm{kV}$ voltage & & \\
\hline 17 & $\begin{array}{l}\text { 17.1. The construction of the OHL } 400 \mathrm{kV} \text { Oradea Sud - } \\
\text { Nădab at a voltage } 400 \mathrm{kV} \text {; }\end{array}$ & $\mathbf{U}$ & $\mathbf{S}$ \\
\hline
\end{tabular}

\section{Conclusions}

According to follows of the risk assessment of energy security on critical infrastructure (power substations and power overhead lines) within NPG, we have identified 26 vulnerabilities: 13 internal vulnerabilities with internal impact within NPG, 4 external vulnerabilities with external impact within NPG, and 9 external vulnerabilities within neighbouring power systems with internal impact on NPG.

The need to identify vulnerabilities of critical infrastructures in the NPG apparent from the following considerations: knowing the fact that NPG is of national strategic importance, it should be assessed and continuously monitored in terms of security risks in order to identify vulnerabilities, the need for security risk assessment comes from a European perspective because Romania is interconnected ENTSO-E (European Union power system), by knowing the vulnerabilities, we can automatically identify dangers and threats that NPG is subject engaged and create measures or national strategy to protect and secure critical infrastructures national/European, and specific risk scenarios developed a high level of risk with devastating effects on national security.

The identified vulnerabilities are eliminated by National Energy Strategy 2021 - 2036 (short, medium, and long term) proposed by the authors, with the aim of increasing energy and national security, resulting from the following: $\mathbf{5}$ solutions: $\mathbf{U}$ - Urgently in $\mathbf{S}$ - Short Period/Term (1 - 5 years): point 4 (4.1.); point 14 (14.1.); point 15 (15.1.); point 16 (16.1.; 16.2.); point 17 (17.1.), 7 solutions: VI - Very Important in $\mathbf{M}$ - Medium Period/Term (5 - 10 years): point 1 (1.1.; 1.2.; 1.3.); point 2 (2.1.; 2.2.); point 3 (3.1.; 3.2.; 3.3.); point 5 (5.1.; 5.2.); point 6 (6.1.; 6.2.; 6.3.); point 10 (10.1.; 10.2.); point 11 (11.1.; 11.2.; 11.3.), and 
5 solutions: I - Important in L - Long Period/Term (10 - 15 years): point 7 (7.1.; 7.2.); point 8 (8.1.; 8.2.; 8.3.; 8.4.); point 9 (9.1.; 9.2.); point 12 (12.1.; 12.2.); point 13 (13.1.; 13.2.).

Energy security vulnerability should be prevented, combated and eliminated through major investments in power infrastructure (power substations, overhead power lines and power plant) and qualified personnel in following activity regarding electrical installation high, very high and ultra high voltage: operational, maneuvers, maintenance, dispatch, occupational health and safety, critical infrastructures protection and emergency or crisis response.

\section{References}

1. C. Bahnareanu, Energy security, Center for Strategic Defense and Security Studies, "Carol I" National Defense (UPH, Bucharest, 2008)

2. N. D. Fita, Research on the identification of critical infrastructure vulnerabilities in the national power grid at ultra-high and very-high voltage, with international connection, Thesis of Doctorate, (2020)

3. N.D. Fita, Identifying vulnerabilities of critical infrastructures from national power grid in the context of increasing enegy security (UPH, Petrosani, 2019)

4. N.D. Fita, R. Moraru, G. Babut, D. Pasculescu, L. Pana, M. Badica, N. Visan, Electrical safety of critical infrastructures and personnel within the national power grid (UPH, Petrosani, 2019)

5. N.D. Fita, R. Moraru, Strategii de securitate a infrastructurilor critice asupra instalațiilor de ultra inaltă și foarte inaltă tensiune din cadrul sistemului electroenergetic național în context european, Academia Națională de Informații "Mihai Viteazul" - Conferința Științifică a Școlii Doctorale "Informații și Securitate Națională", Bucureşti, (2016)

6. L. Pana, J. Grabara, D. Pasculescu, V.M. Pasculescu, R.I. Moraru, Optimal quality management algorithm for assesing the usage capacity level of mining tranformers, Polish Journal of Management Studies, 18 (2), 233-244, (2018)

7. D. Pasculescu, L. Pana, V.M. Pasculescu, F. Deliu, Economic criteria for optimizing the number and load factor of mining transformers, Mining of Mineral Deposits, 13 (2), 1-16, (2019)

8. A.D. Handra, F.G. Popescu, D. Pasculescu, Utilizarea energiei electrice - lucrări de laborator, (UPH, Petrosani, 2020)

9. F.G. Popescu, D. Pasculescu, V.M. Pasculescu, Modern methods for analysis and reduction of current and voltage harmonics, (LAP LAMBERT Academic Publishing, 2020)

10. F. G. Popescu, D. Pasculescu, M. D. Marcu, V. M. Pasculescu, Analysis of current and voltage harmonics introduced by the drive systems of a bucket wheel excavator, Mining of Mineral Deposits, 14 (4), 40-46, (2020)

11. F. G. Popescu, D. Pasculescu, M. Marcu, T. Niculescu, A. D. Handra, The technical and economic advantages of power factor correction, Annals of University of Petrosani, Electrical Engineering, 21, 35-42, (2019)

12. M.D. Marcu, L. Pana, F.G. Popescu, R. Slusariuc, Evaluation the losses power and electrical energy on the basis of the relative load curves, by reference to the basic sizes. Proceedings of the 18th International Multidisciplinary Scientific Geoconference SGEM 2014 14, 229 - 236, (2014)

13. N.D. Fita, C. Barb, D. Pasculescu, L. Pana, The description and evaluation of technical incident risk on the National Power Grid in the context of power safety growth, 9th International Conference on Manufacturing Science and Education (MSE) - Trends in New Industrial Revolution, 290, 12010, (2019)

14. T. Niculescu, V. Arad, M. Marcu, S. Arad, F. G. Popescu, Safety barrier of electrical equipment for environments with a potential explosion in underground coal mines, Mining of Mineral Deposits, 14 (3), 78-86, (2020)

15. G. Buica, A.E. Antonov, C. Beiu, D. Pasculescu, R. Dobra, Occupational health and safety management in construction sector - the cost of work accidents, Supplement of Quality-Access to Success, 18 (S1), 35-40, (2017) 